\title{
BIOLOGICAL CONTROL OF NATURAL HERBIVORES ON AMBROSIA SPECIES AT LIAONING PROVINCE IN NORTHEAST CHINA
}

\author{
IQBAL, M. F. ${ }^{1}-$ FENG, W.-W. ${ }^{1}-$ GUAN, M. ${ }^{1,2}-$ XIANG, L.-Z. ${ }^{1}-$ FENG, Y.-L. ${ }^{*}$ \\ ${ }^{1}$ Liaoning Key Laboratory for Biological Invasions and Global Changes, College of Bioscience and \\ Biotechnology, Shenyang Agricultural University, Shenyang 110866, Liaoning Province, China \\ ${ }^{2}$ School of Life Sciences, Taizhou University, Taizhou 318000, Zhejiang Province, China \\ *Corresponding author \\ e-mail: yl_feng@tom.com; phone: +86-24-8848-7163; fax: +86-24-8849-2799
}

(Received $16^{\text {th }}$ Sep 2019; accepted $15^{\text {th }}$ Nov 2019)

\begin{abstract}
Giant ragweed (Ambrosia trifida L.) and Common ragweed (Ambrosia artemisifolia L.) are well known species native to North America and can now be found in China. These weeds are ecologically important and have the ability to spread into agricultural areas and can create future risks. This study is an attempt to investigate the control potential of the root, a pathogen and a gall forming stem insect herbivore for Ambrosia species at different locations of Liaoning Province in Northeast China. Significantly $(\mathrm{P}<0.05)$ high pathogen herbivore (Puccinia xanthii) abundance was investigated in sites IV and II $(16.76 \% ; 14.04 \%)$ with 58-66\% humidity at site temperature ranges between minimum-maximum $\left(20-30^{\circ} \mathrm{C}\right)$. Significant abundance $(\mathrm{P}<0.05)$ in stem gall insect herbivore (Epiblema strenuana) were recorded in site IV $(12.49 \%)$ and site I (12.34\%). This herbivore displayed a steep asymptotic curve decrease significantly from upper to lower position gave positive relationship. The value of co-efficient of determination $\left(R^{2}=0.52\right)$ as depicted gave the indication of model fitness. Pathogen herbivore displayed also a steep asymptotic curve investigated moderate positive relationship with $R^{2}=0.45$ followed by site I $\left(R^{2}=0.36\right)$ form parabola curve. Stem galling insect and pathogen herbivores were diversified significantly with Simpson's index of diversity (SID). Similarly, root herbivore (fire ant) demonstrated its biological control potential on invasive Ambrosia artemisifolia at site I recorded significant $(\mathrm{P}<0.05)$ reduction in plant height $(30.62 \%)$; diameter $(43.21 \%)$ and number of leave $(73.60 \%)$ compared to gall forming stem herbivore.
\end{abstract}

Keywords: damage level, Epiblema strenuana, invasiveness, potential, Puccinia xanthii, Solenopsis invicta

\section{Introduction}

Invasive alien species (IAS) create hazard and develop a key pressure on biodiversity of the world that alter ecosystem, reduce native species abundance and cause economic loss (Butchart et al., 2010; Vilà et al., 2011; Hejda et al., 2009; Buttenschøn et al., 2010). However, there is a dire need to react and develop strategies against this hazard should be a basic goal (Lambertini et al., 2011).

Common ragweed (Ambrosia artemisifolia L.) is an annual invasive weed belongs to family asteraceae native to North America and Mexico present all over the world (Fig. 1) and also in China (Zhou et al., 2017). This weed unintentionally introduced in south east coastal areas in China in 1930's (Chen et al., 2007; Wan et al., 1995). Invasive weeds can affect ecosystem processes, alter community structure and resulting in loss of native weeds populations (Hejda et al., 2009; Powell et al., 2011). Ambrosia species introduced as noxious invasive weed in southern area of European Russia, Europe that extends into Georgia and westwards into Ukraine (Moskalenko, 2002; Reznik, 2009; Bullock et al., 2012; Essl et al., 2015; Protopopova et al., 2006; Ustinova and Sizovenko, 2006). This weed infested on agricultural crops (oilseed, rapeseed crop, 
sunflower and soybean) as well as on fallow land resulted significant yield losses (Kazinczi et al., 2008; Buttenschøn et al., 2010; Tóth et al., 2004; Kőmíves et al., 2006; Chollet, 1999; Moskalenko, 2002).

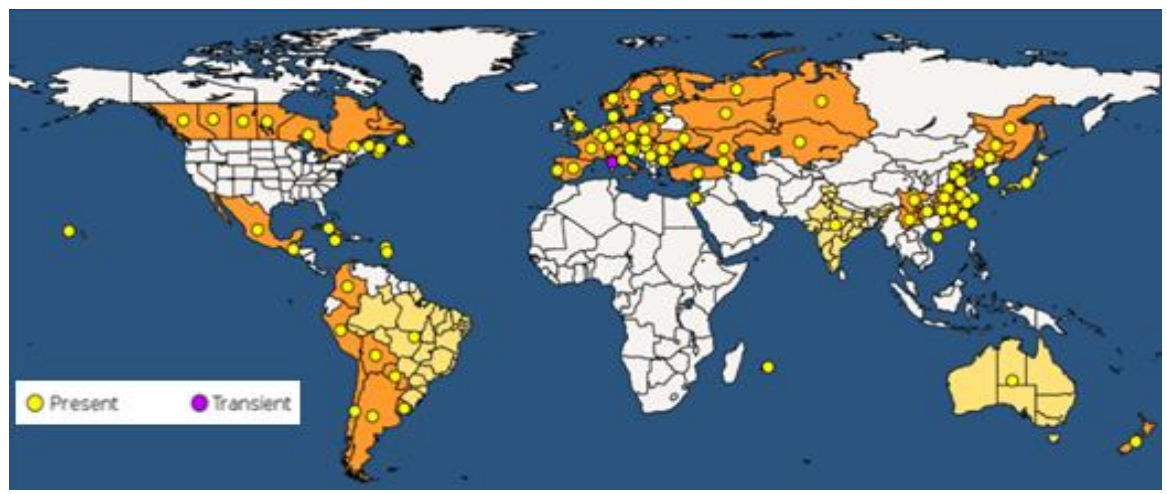

Figure 1. Distributional map and invasion status of Common ragweed (Ambrosia artemisifolia) around the globe (EPPO, 2008)

Giant ragweed (Ambrosia trifida L.) is an annual herb with branched, erect stems with $30-150 \mathrm{~cm}$ in height which prolong up to $400 \mathrm{~cm}$. Their leaves were mostly opposite, slightly scabrous, elliptical, 3-5 lobes, margins usually dentate, petioles with 10-30 $\mathrm{mm}$ in size (Strother, 2006). This is the most competitive weed in row crops which evolved resistance against multiple herbicides (Goplen et al., 2016). Ambrosia species dispersed in 21 provinces in eastern part of China including Jiangxi, Hunan, Hubei, Anhui, Fujian, Zhejiang, Nanjing, Jiangsu (Zhou et al., 2014; Zhou et al., 2010; Meng and Li, 2005) and this weed is polymorphism in nature (Bassett and Crompton, 1975). There is extensive history of biological control against Ambrosia species in Eastern Europe, Australia, China and Kazakhstan (Fig. 2).

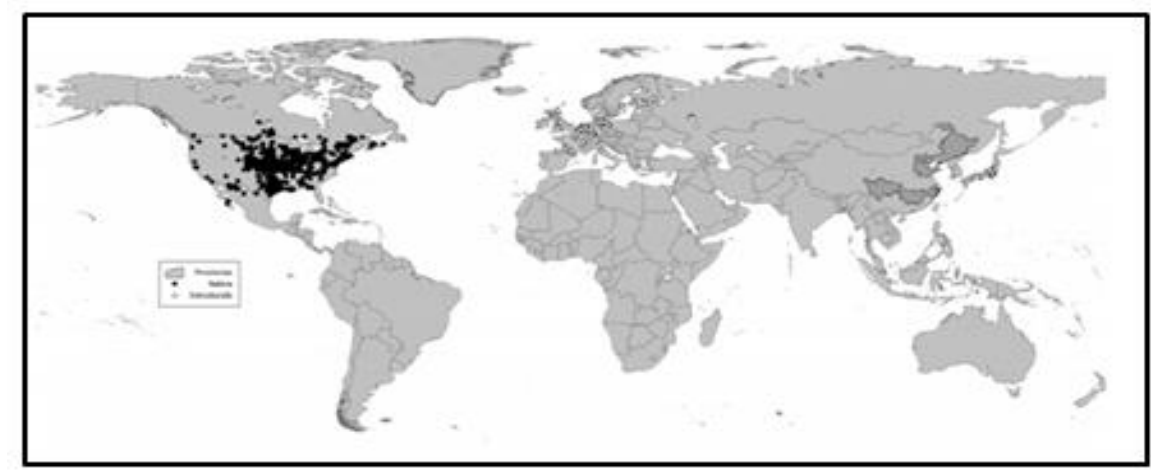

Figure 2. Distributional map and invasion status of Giant ragweed (Ambrosia trifida) around the globe (GBIF, 2018; Committee, 2011)

Epiblema strenuana (Walker) (Lepidoptera: Tortricidae) is an endemic and widely distributed in North America, Canada, Mexico and USA, Arkansas, California, Colorado, Connecticut, Columbia, Florida, Illinois, Maryland, New Jersey, New York, North Carolina, Ohio, Pennsylvania, Tennessee, Virginia (Heinrich, 1923), Iowa, Mississippi, Dakota (Brown, 1973) and Israel (Yaacoby and Seplyarsky, 2011). 
Rust is a pathogen herbivore (Puccinia xanthii), the most promising candidate for biological control of Ambrosia species (Hennen et al., 2005). P. xanthii collected on A. trifida in North America recorded high level of specificity to its original host named P. xanthii f. sp. ambrosiae-trifidae (Batra, 1981), however, this pathogen did not show its infection on A. artemisiifolia (Kiss, 2007; Morin et al., 1993). The significant impact of $P$. xanthii having its host documented in China on Ambrosia trifida caused serious die-back of infected plants (Lu et al., 2004a).

Fire ants (Formicidae: Hymenoptera) are social insects reside in colonies that habitually fabricate hills/mounds/tunnels within the soil like pastures and arable lands. Their nests are present within the soil, under stones, or in trees.

The stem galling insect herbivore (Epiblema strenuana) was introduced from Australia to China and host specificity tests were conducted on sunflower crops (Zhao et al., 2014; Wan et al., 1995), however, insect herbivore was introduced in 1990 to control A. artemisifolia. The insect release in a small-scale in Hunan Province, and later the insect established its population and began to spread. Host specificity and feeding studies indicated that there are four host plants (A. artemisifolia, A. trifida, Xanthium sibiricum and Parthenium hysterophorus) were discovered in China (Ma et al., 2003).

There is an intensive need to locate and develop eco-friendly solutions regarding biological control agents (BCA's) for the proper management of invasive weeds (McFadyen, 1998). These weeds produced allergic pollens that cause pollution and considered significant possible hazard to human beings and the natural diversity (Qureshi et al., 2014). The most important key provoking strategies to control these invasive weeds are chemicals. The chemical industry of China has taken one of the most re-known positions in global village. Many broad, narrow and sedges type of invasive and non invasive weeds were controlled by herbicides. These chemical herbicides create negative impacts on the natural ecosystem may cause toxicity to human beings (Bastiaans et al., 2008; Wilson and Tisdell, 2001; Zhang et al., 2011b).

To overcome the problem of excessive usage of chemicals; biological control agents are the best option without posing contamination to environment and naturally growing populations. The study hypothesis is that the damage level of pathogen herbivore (Puccinia xanthii) may vary with locations depend upon the prevailing environmental conditions and to find out insects having biological control efficiency against invasive weeds. The study comprised the relationship between root and stem galling insect herbivores against Ambrosia artemisifolia in relation to plant growth parameters. However, the survey was conducted to point out coefficient of determination $\left(R^{2}\right)$ of natural herbivores associated with Ambrosia trifida and to study diversity of natural herbivores with Ecological Indices on Ambrosia trifida at four locations. This survey was planned under Liaoning Key Laboratory for Biological Invasions and Global Changes, College of Bioscience and Biotechnology, Shenyang Agricultural University (SYAU), Shenyang, Liaoning Province, People Republic of China during 2018.

\section{Materials and Methods}

The field survey was conducted to evaluate root herbivore fire ant (Solenopsis invicta); gall forming stem herbivore (Epiblema strenuana) and pathogen herbivore (Puccinia xanthii) studied as biological control agents (BCA's) on invasive ragweed species (Ambrosia artemisifolia and $A$. trifida) at different sites. However, minimum and maximum temperature was recorded on the spot site having site I $\left(22-31^{\circ} \mathrm{C} \& 69 \%\right.$ humidity); site II $\left(21-30^{\circ} \mathrm{C} \&\right.$ 
$66 \%$ humidity); site III $\left(21-34^{\circ} \mathrm{C}\right.$ with $\left.62 \% \mathrm{RH}\right)$ and site IV $\left(20-30^{\circ} \mathrm{C}\right.$ with $\left.58 \% \mathrm{RH}\right)$ as shown (Fig. 3). The study was conducted in peak season keeping in view the pressure of the herbivores are maximum in July-August during 2018 (Fig. 4).

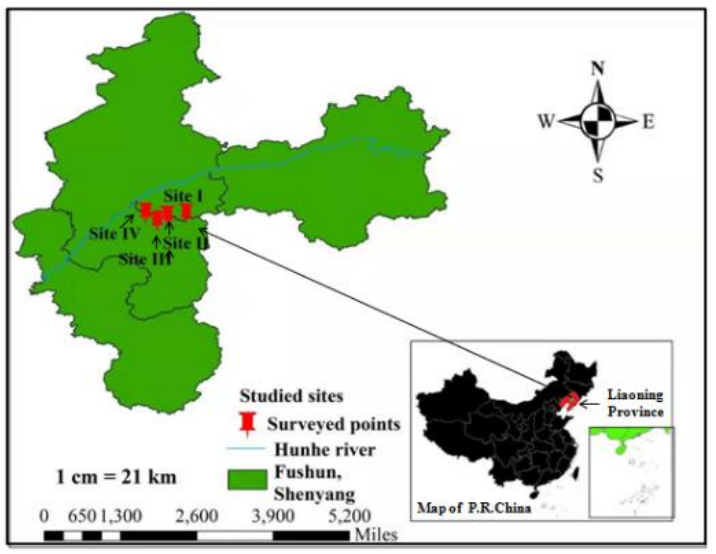

Figure 3. Mapping location of biological control agents (Epiblema, Puccinia and Solenopsis) using ArcGIS software (Kumar et al., 2014)
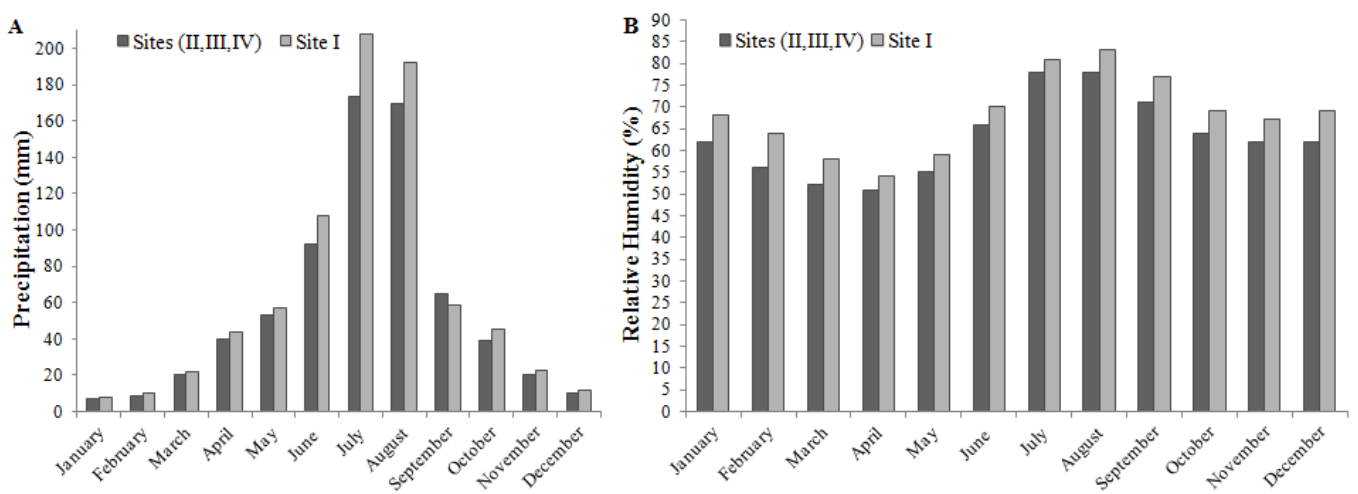

Figure 4. The climatic data showing mean monthly precipitation (A); Monthly mean Relative Humidity (B) of four sites (data sourced from Chinese meteorological data base)

The studied area is a northeastern part in China having hilly area at the boarder of South Korea. The average annual rainfall of site I was recorded $786.8 \mathrm{~mm}$ with range of annual relative humidity 54-83\%. However, the site II, III, IV having annual rainfall were recorded $698.5 \mathrm{~mm}$ with range of annual relative humidity 51-78\% (Fig. 4A,B).

The approach used was a simple random sampling technique designed through extensive field survey (Iqbal et al., 2019). The transect line was eighty meter long parallel to the roadside or riverside; however, we collected four different points twenty meters in one side of transect and data were recorded using quadratic ring (Murphy et al., 2015; Riaz and Javaid, 2011; Zereen et al., 2018; Iqbal et al., 2019) having (100 x $100 \mathrm{~cm}$ ) following standard protocol (Andersen et al., 2015). Our sampling focused on stem galling insect and pathogen herbivores consumed directly on the leave and stem on Ambroia trifida at four locations. The data of root with gall forming herbivore were recorded in site I on Ambrosia artemisifolia due to the availability of both herbivores at this site. The root herbivore of common ragweed plants present in each quadratic ring 
was collected and same procedure was adopted for control for proper comparison. The nine damaged leaves collected randomly from the upper, middle and lower portions of $A$. trifida, and repeat this procedure three times. The insect galled stems in $A$. artemisifolia were also collected in a quadratic ring counted the number of galls and repeated thrice. The A. trifida leave spread fully on the hardboard with white background and cover it by transparent flexible plastic cover for digital image analysis. We evaluated and quantify herbivore damage on A. trifida leaves by Adobe Photoshop and ImageJ at maximum entropy (MaxEnt) threshold (Moles and Westoby, 2000; Lowman, 1984; Goodwin and Hsiang, 2010; O’Neal et al., 2002). Then leaf area fed/consumed (\%) by natural herbivores were assessed (Balami and Thapa, 2017).

At the end, total number of healthy and damaged leave were counted for the calculation of damage percentage (Balami and Thapa, 2017). Simpson index of Diversity (SID), evenness and abundance values were calculated (Magurran, 1988; Qureshi et al., 2018; Mahajan and Fatima, 2017; Chao et al., 2005; Letourneau et al., 2009; Kilewa and Rashid, 2014; El-Azazi et al., 2013).

The consumed area by Puccinia xanthii recorded on A. trifida leaves collected from these locations and examined under microscope (Iqbal et al., 2019) with $40 \mu \mathrm{m}$ and 100 $\mu \mathrm{m}$ magnifications. The root, stem and pathogen herbivore were identified by morphometric characteristics (McClay, 1987; Bincheng, 1994; Yaacoby and Seplyarsky, 2011; Wahyuno, 2012; Batra, 1981).

\section{Re-modification of the evolving model}

The regression-type relationship carried out for developing the model comparison between mean of natural herbivore fed sites with root mean square error (RMSE). The regression model was set out to determine the effect natural herbivores consumed plant/leave parts investigated different parameters, gave the information about how far away the predicted line is from the observed line. The researchers previously exposed how scattered the observed points around the predicted line, which alternatively revealed about the validity of the model fitness (Hossain et al., 2017; Debaeke et al., 1997; Ahmed et al., 2019). RMSE gave magnitude of the characteristic variation between predicted and observed data (Mayer and Butler, 1993) resulted to assess the precision of the model (Royo-Esnal et al., 2010; Iqbal et al., 2019).

\section{Statistical analysis}

The growth parameter analyzed by one-way analysis of variance with Tukey's HSD test keeping in view $\mathrm{P}>0.05$; however, coefficients of determinations $\left(R^{2}\right)$ were calculated by means of respective sites. The geographic coordinates during survey site was recorded using GPS navigator (GPS-Hollox, Taiwan) and map was drawn on ArcGIS version 10.2 software (ESRI) (ArcGis, 2013).

\section{Results}

\section{Response of natural herbivores on Giant Ragweed (Ambrosia trifida L.)}

Validation of the model fitness

The gall forming stem herbivore (Epiblema strenuana) after emergence fed on $A$. trifida leave at four different sites gave indication that site II and IV displayed a steep asymptotic curve decrease significantly from upper to lower position. This curvature 
went in upward direction investigated moderate strength of the variables that gave positive relationship. However, coefficient of determination was recorded in site II $\left(R^{2}=\right.$ $0.52)$ followed by site I $\left(R^{2}=0.49\right)$ showed linear line. In site IV, coefficient of determination $\left(R^{2}=0.43\right)$ was recorded polynomial positive interactions of the model fitness as depicted (Fig. 5A,B) compared to site III $\left(R^{2}=0.02\right)$ having line parallel to $\mathrm{X}$ axis recorded no relationship of herbivore with its calculated consumed leave $(\%)$.

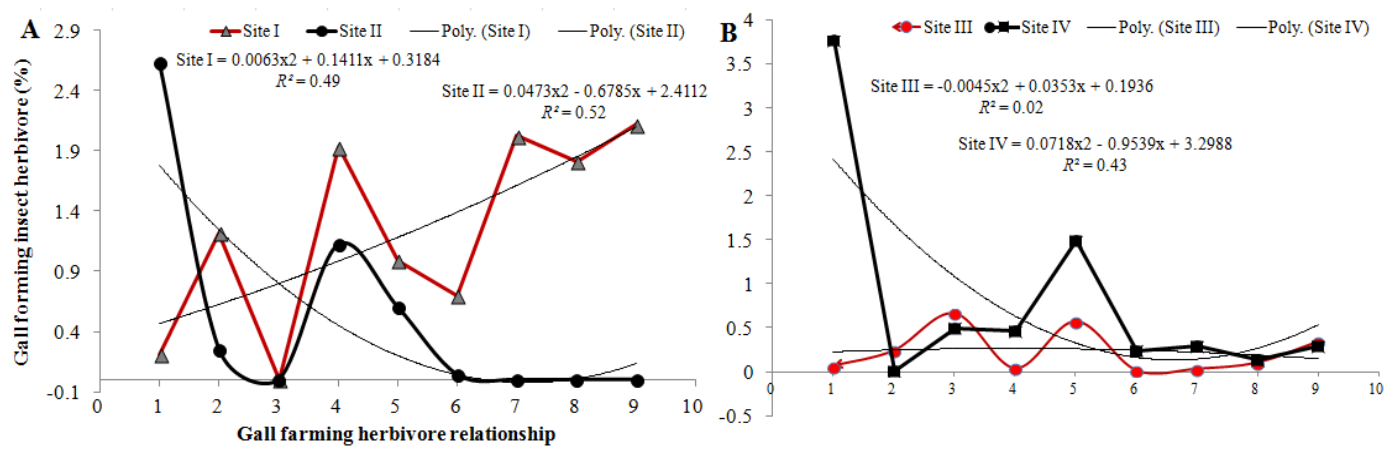

Figure 5. Power relationship of gall forming stem herbivores feeding (\%) on A. trifida leave with different sites; whereas Site I and II (A); III and IV (B); $R^{2}=$ Co-efficient of determinations; Poly means Polynomial

The affect of natural insect herbivore feeding (\%) on A. trifida leaves were investigated non significant $(\mathrm{P}>0.05)$ relationship at all four sites, therefore the value of root mean square error (RMSE) $<5$ recorded in our experiment gave the indication of model fitness (Table 1). The pathogen herbivore recorded significant $(\mathrm{P}<0.05)$ effect in site II on A. trifida leave with the leave feeding rate (7.78\%) with RMSE (3.15) compared to the rest of the studied sites.

Table 1. Relationship of RMSE with affect of natural stem galling and pathogen herbivore (\%) on A. trifida leave at different locations during 2018

\begin{tabular}{c|c|c|c|c}
\hline Locations & GFSH \pm SE & RMSE & PH \pm SE & RMSE \\
\hline Site I & $1.22 \pm 0.27^{*}$ & 0.30 & $3.25 \pm 1.89$ & 3.13 \\
\hline Site II & $0.52 \pm 0.29^{*}$ & 0.27 & $7.78 \pm 1.55^{*}$ & 3.15 \\
\hline Site III & $0.23 \pm 0.08^{*}$ & 0.25 & $1.17 \pm 0.20$ & 3.12 \\
\hline Site IV & $0.80 \pm 0.40^{*}$ & 0.28 & $5.98 \pm 1.27$ & 3.14 \\
\hline
\end{tabular}

Whereas level of significance was $\mathrm{P}<0.05$, RMSE - root mean square error; GFSH - means gall forming stem insect herbivore (\%); $\mathrm{PH}$ - means pathogen herbivore (\%); $\mathrm{SE}$ - standard error

The pathogen herbivore investigated on A. trifida leave described that site II and I displayed a steep asymptotic curve decrease significantly from upper to lower side. At the end of the streak curvature went in upward direction investigated moderate positive relationship with the value of coefficient of determination $\left(R^{2}=0.45\right)$ followed by site I $\left(R^{2}=0.36\right)$ and falls this polynomial curve on the ground like parabola. Same trend line was recorded in Site IV with $R^{2}=0.14$ described polynomial positive weak interactions of the studied model soundness as illustrated (Fig. 6A,B) compared to site III $\left(R^{2}=0.03\right)$ have no significant relationship with herbivore feeding or consumed $(\%)$. 

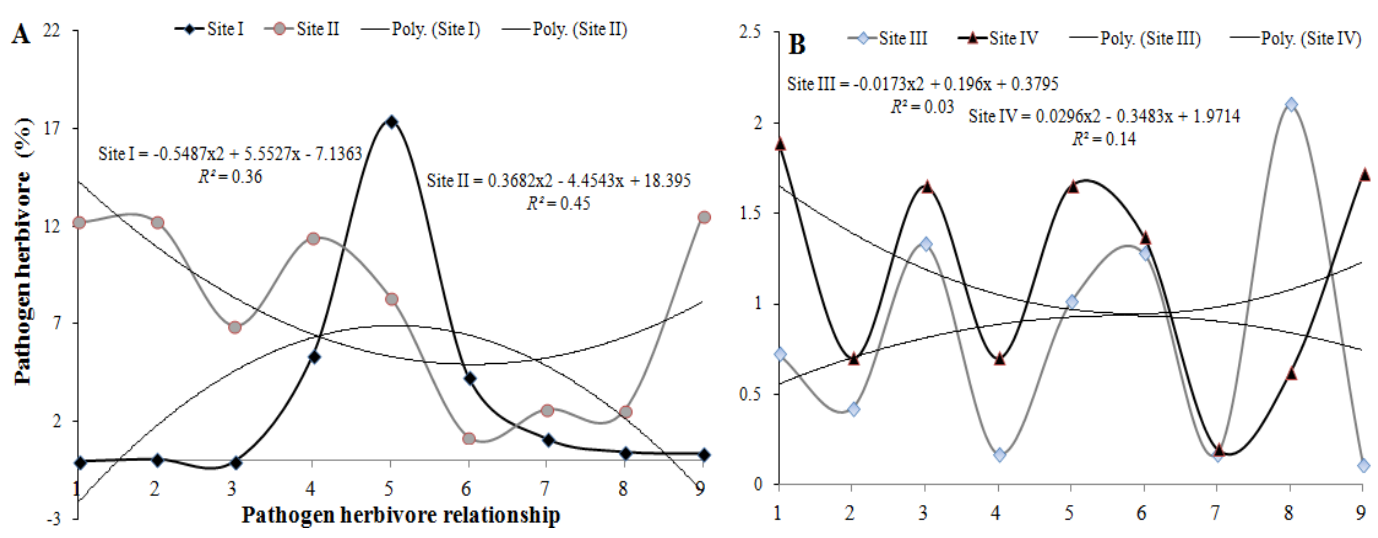

Figure 6. Power relationship of pathogen herbivore feeding (\%) on A. trifida with different sites whereas site I and II (A); III and IV (B); $R^{2}$ (Co-efficient of determinations); Poly (Polynomial)

\section{Ecological indices}

Maximum evenness of gall forming insect (Epiblema strenuana) herbivore was investigated on site I \& IV $(0.15 \& 0.15)$ recorded more stable in the community followed by site II (0.13) and site III (0.08). Similarly this herbivore was also more diversified in site I and IV (0.86 and 0.85) compared to other sites.

Maximum evenness of pathogen herbivore was investigated on site II \& IV $(0.15 \&$ $0.15)$ recorded maximum stability in the community followed by site I $(0.13)$ and site III (0.12). Pathogen herbivore was more diversified in site II and IV produced simpson's index of diversity 0.91 and 0.88 respectively (Fig. 7).

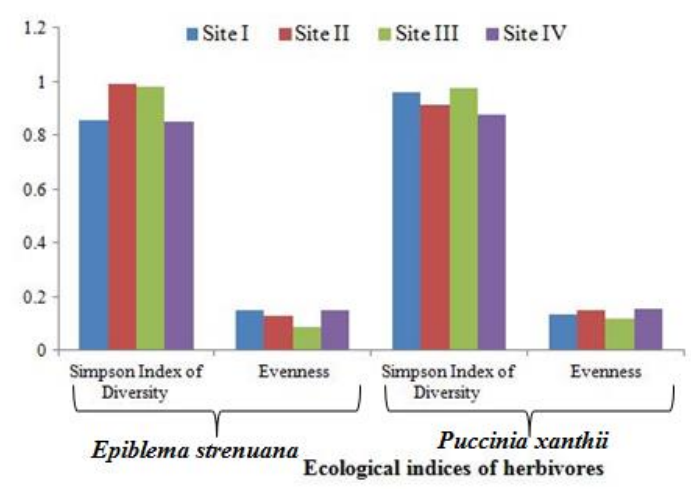

Figure 7. Ecological indices of gall forming insect and pathogen herbivores on A. trifida

The maximum pathogen herbivore abundance $(\%)$ per plant recorded in site IV $(16.76 \%)$ followed by site II $(14.04 \%)$. Similarly, highly significant $(\mathrm{P}<0.05)$ abundance in leave consumed was determined by gall forming stem herbivore at site IV $(12.49 \%)$ followed by site I (12.34\%) which was comparable to the other sites (Fig. 8A). Further more high number of leaves (12.22 and 14.56) consumed by gall forming insect and Puccinia xanthii herbivores respectively at location IV which differed significantly $(\mathrm{P}<0.01)$ compared to all other sites (Fig. 8B). 

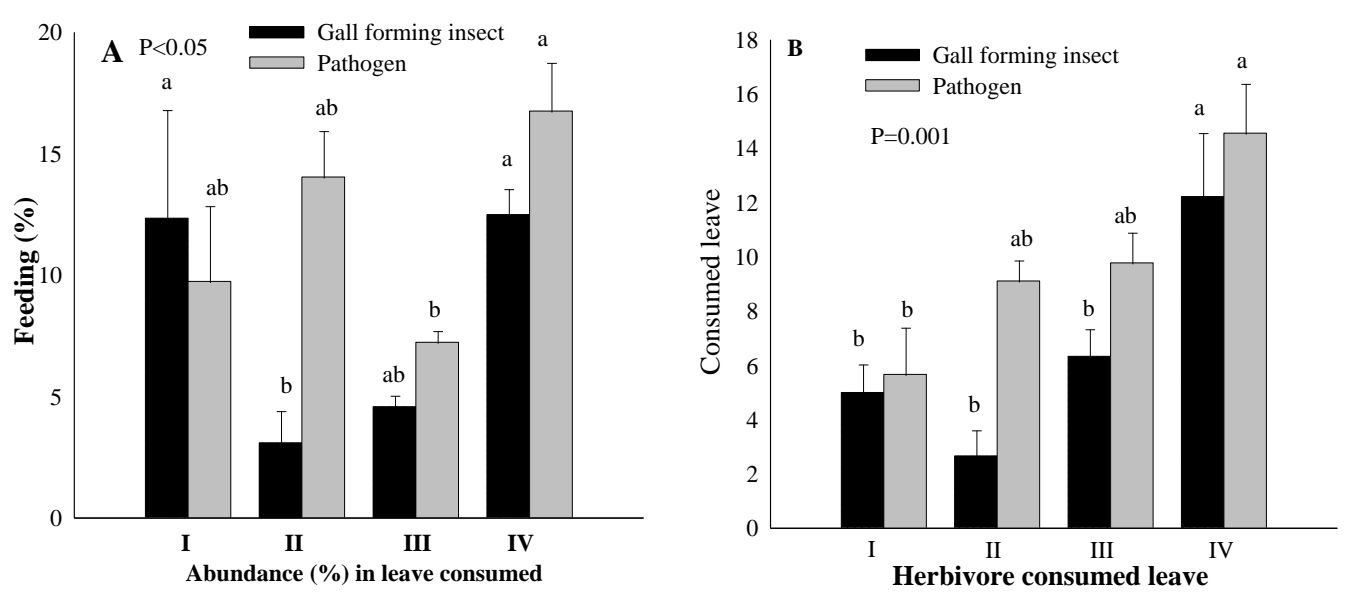

Figure 8. Comparison of abundance (\%) in leave consumed/plant by gall forming insect

(Epiblema strenuana) and pathogen (Puccinia xanthii) herbivores (A), number of leave consumed by herbivores $(B)$ at four locations during 2018. Whereas level of significance was $P<0.05$ by Tukey's HSD test for each response variable; the mean having different lettering differ statistically from each other

\section{Response of natural herbivores on common ragweed (Ambrosia artemisifolia L.)}

\section{Plant growth parameters}

The result of this study recorded significant $(\mathrm{P}<0.05)$ increase in total number of leaves $(74.70 \%)$ with $\mathrm{F}=138.416$; $\mathrm{SS}=9202.722$ in control treatment comparable to the root herbivore in quadratic rings. However, significant $(\mathrm{P}<0.05)$ increase in plant height $(\mathrm{cm})$ with $(\mathrm{F}=74.729$ and $\mathrm{SS}=4461.976)$; diameter $(\mathrm{mm})$ were $(34.16 \%)$ with $(\mathrm{F}=55.106 ; \mathrm{SS}=26.451)$ and $(33.90 \%)$ with in control compared to root herbivore (Fig. 9A,B,C).
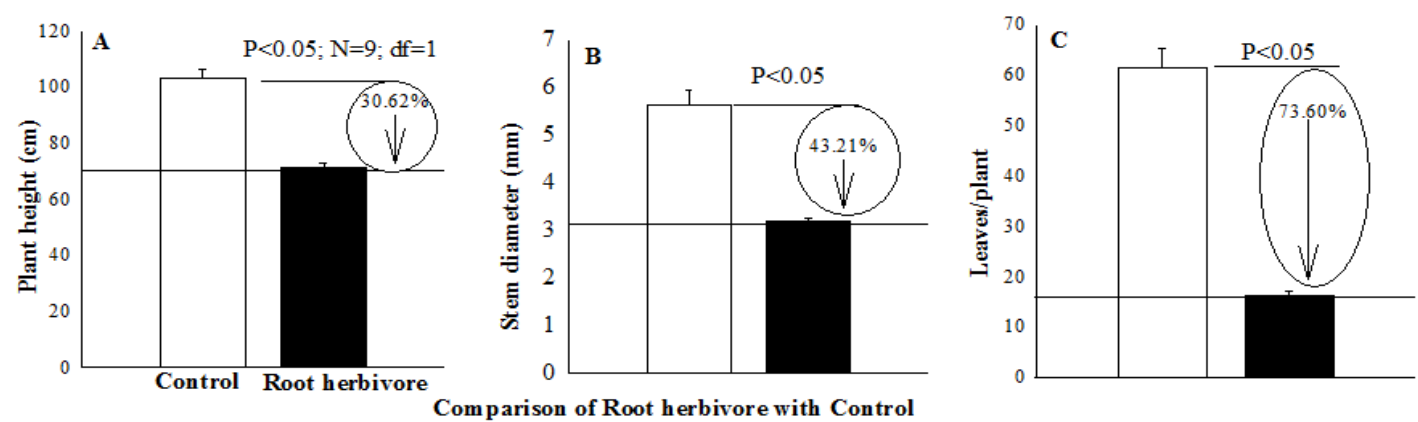

Figure 9. Comparative efficiency of root herbivore affected on growth parameters of Ambrosia artemisifolia L. during 2018 whereas (A) plant height (cm), (B) stem diameter $(\mathrm{mm}),(C)$ total number of leaves per plant. Whereas level of significance was $P<0.05$ by Tukey's HSD test

The analysis showed that root herbivore distributed at site I showed its biological control potential against common ragweed. These results suggested that the trend of plant height (30.62\%), stem diameter (43.21\%) and the number of leaves (73.60\%) of $A$. artemisifolia decreased significantly due to biting behavior of root herbivores on the roots zone compared to control. 


\section{Comparative efficacy of herbivores}

The data regarding root herbivore showed non significant $(\mathrm{P}>0.05)$ result on replicated plots at three different sub locations in site I with each other but recorded significant $(\mathrm{P}<0.05)$ result with gall forming stem herbivore. The data described that root herbivore reduced the plant height significantly $(\mathrm{P}<0.05)$ of the invasive A. artemisifolia compared to stem feeding herbivore (Fig. 10A). Furthermore, the same significant $(\mathrm{P}<0.05)$ trend was investigated in case of stem diameter $(\mathrm{mm})$ to control A. artemisifolia (Fig. 10B). Multivariate analysis suggested that biological control herbivores recorded significant $(\mathrm{P}<0.05)$ reduction in growth parameters of invasive weed compared to control.
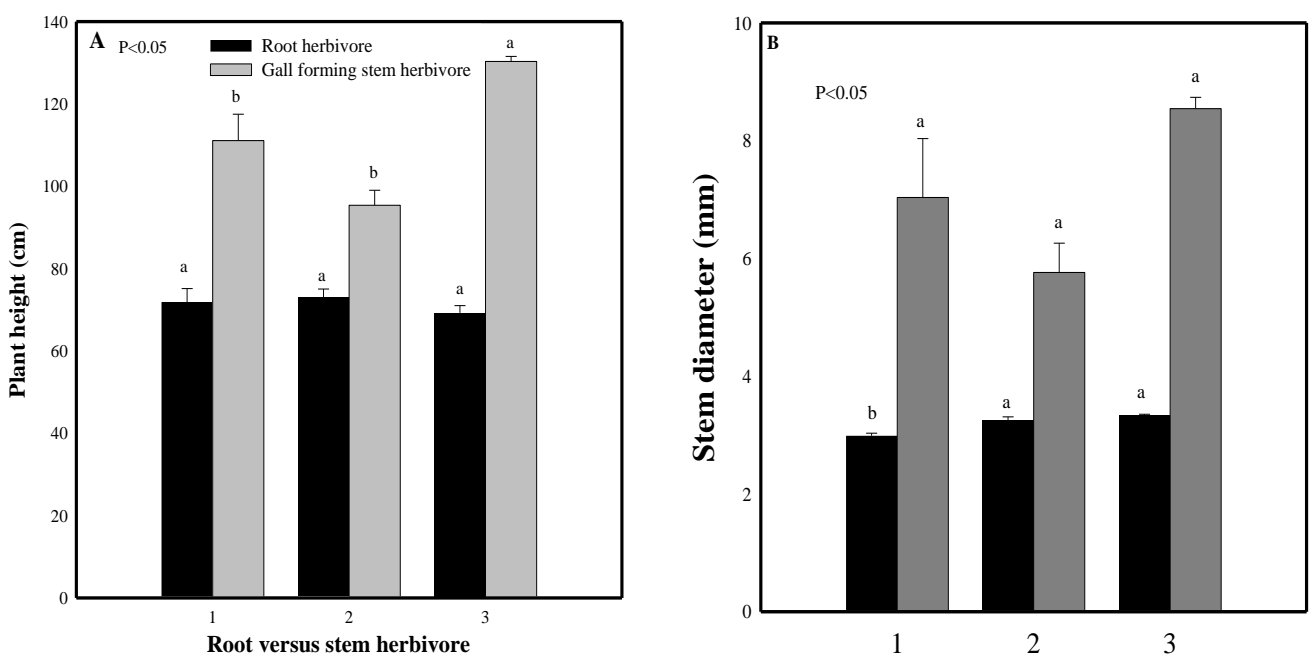

Figure 10. Comparative efficacy of root and gall forming stem herbivore on plant height (A); stem diameter (B) of Ambrosia artemisifolia at $\alpha=0.05$ (Tukey's HSD test), for each response variable at site I; the mean having different lettering differed statistically from each other

\section{Discussion}

\section{Relationship of gall forming herbivore with Ambrosia trifida $L$.}

The infestation of gall forming insect herbivore used as biological control agent on A. trifida displayed a steep asymptotic curve decrease significantly gave polynomial positive and moderate relationship of coefficient of determination $\left(R^{2}\right)$ indicated model fitness as depicted. This insect herbivore fed on leaf tissues (\%) was produced statistically non significant $(\mathrm{P}>0.05)$ relationship (Table 1) with root mean square error $(\mathrm{RMSE}=0.30)$. These results were supported to the researchers who reported that the value of RMSE investigated less than 5 gave the indication of awesome model fitness (Royo-Esnal et al., 2010; Iqbal et al., 2019).

Significant evenness was recorded by gall insect herbivore investigated on site I \& IV $(0.15 \& 0.15)$. This herbivore was more diversified in site I and IV $(0.86,0.85)$ compareable to the other sites. These results are inaccordance to the researchers who reported that A. trifida L. occured in Northeast China, in heavily infested areas, ragweeds were often found in dense monospecific communities with an average diversity index of 0.19 (Wan et al., 1995). Ambrosia species an annual weed plant present almost everywhere in China and prefers open and sunny habitats where its 
competition with other native weed is comparatively low. Ambrosia species reduced the natural species abundance in arable land and thus it investigated negative impacts on the agriculture and biodiversity (Pinke et al., 2011; Pál, 2004). The present investigation stated that stem insect herbivore larvae after hatching fed initially on Ambrosia trifida leave. After that the larvae enter on the terminal meristem, thickens the stem thus creating elongated galls in plants live there until it pupates. Highly significant $(\mathrm{P}<0.05)$ abundance in leave consumed by stem gall forming herbivore investigated $12.49 \%$ and $12.34 \%$ in plant. Gall forming stem herbivore consumed high number of leaves 12.22 per plant at site IV differed significantly $(\mathrm{P}<0.01)$ with all other rest of the sites. These results are agreed with the scientists who reported that gall herbivore is a nocturnal moth, with a life span of 7-11 days that feed on the invasive weed (Bincheng, 1994; McFadyen, 1992; Dhileepan and McFadyen, 2001; Dhileepan et al., 2018).

\section{Biological characteristics of gall forming stem herbivore}

The stem-galling herbivore (Epiblema strenuana Walker; Lepidoptera: Tortricidae) lay very small pale color eggs on the leaves (Dhileepan et al., 2018). After hatching eggs, the larvae emerged and fed directly on leave. The length of the larva is about 10 $\mathrm{mm}$ straight, but the length of $3^{\text {rd }}$ instar larva is $14 \mathrm{~mm}$, yellow or creamy, with brown heads with light brown ganitalia. The larva of this herbivore make small hole on the top meristem and branches, enter into plant tissues. The developmental stages completed within the gall and pupate. The color of the pupa is brown, 8-9 $\mathrm{mm}$ long. Pupal stage converted into adult moth under favorable environmental conditions within 5-7 days, however this period prolonged upto 13 days under unfavorable environmental conditions. The open wing span of caterpiller was $15-18 \mathrm{~mm}$ in male and 12-15 $\mathrm{mm}$ wide in females. Adult moths have $10-8 \mathrm{~mm}$ (male-female) long grayish wings with pale glitery wingtips (Fig. 11). There are 3-4 generations of this herbivore that start from the end of April to early October in Southern China and each generation prolong upto 30-40 days (Feng-feng et al., 2002) and the survival time of the adult was 3-5 days under natural environmental conditions at Shenyang.

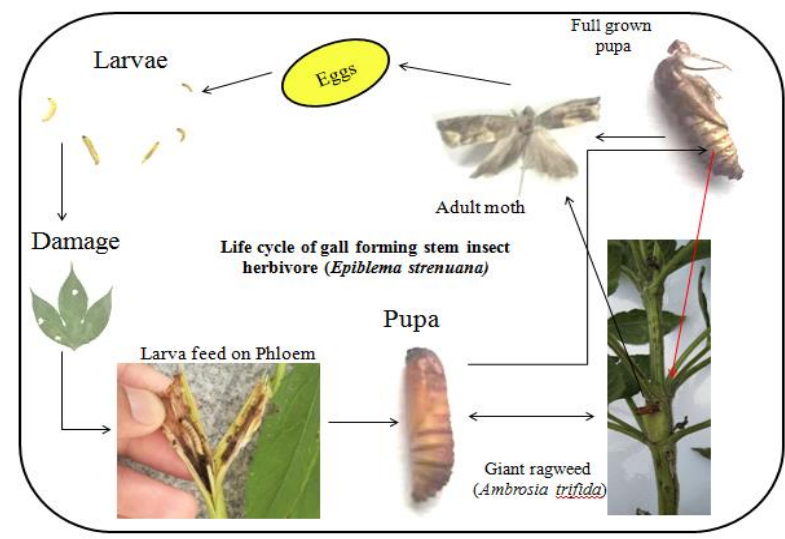

Figure 11. Biological characteristics of gall forming stem herbivore on Ambrosia trifida plant

\section{Relationship of pathogen herbivore with Ambrosia trifida $L$.}

The pathogen herbivore described moderate positive co-efficient of determinations $\left(R^{2}\right)$ in site II $(0.45)$ and site I $(0.36)$, however, weak relationship was recorded in site 
IV and no relationship was determined in site III having its almost line parralel to Xaxis. Maximum evenness of pathogen herbivore (Puccinia xanthii) was investigated on site II \& IV (0.15 \& 0.15$)$ and more diversified in site II (0.91) and IV (0.88) compared to site I and III, respectively. These results are in line with the previously studied field investigations in Liaoning and Jilin provinces reported that pathogen herbivore caused considerable destruction to giant ragweed. The fungus of pathogen herbivore feed on the leaves cause plant death on a large scale and may serve as an effective biological control agent of $A$. trifida (Zhang et al., 2011a; Lu et al., 2004b).

Significantly $(\mathrm{P}<0.05)$ high pathogen herbivore (Puccinia xanthii) abundance was investigated in sites IV and II $(16.76 \%$; 14.04\%) with $58-66 \%$ humidity at site temperature ranges minimum $20^{\circ} \mathrm{C}$ and maximum $30^{\circ} \mathrm{C}$. These results are in accordance to the researchers who reported that this pathogen herbivore (giant ragweed rust) significantly favored high humidity and high temperature for its development. This pathogen was flourished in June-September in Shenyang area (Liaoning Province), so due to its obligate parasitic behavior and strong pathogenicity, this herbivore expected as biocontrol agent for the control of Ambrosia trifida (Qu et al., 2009; Guozhong et al., 2018). Puccinia xanthii herbivore consumed high number of leaves (14.56/plant) at location IV differed significantly $(\mathrm{P}<0.01)$ with all other sites. These results gave the indications that favorable humidity played a significant positive role for spread of pathogen herbivore pressure. These findings support our hypothesis that significant infection of rust herbivore (Puccinia xanthii) on invasive weed may vary with locations depending upon the favorable environmental conditions. The favorable temperature for the germination of teliospore was $20-30^{\circ} \mathrm{C}$ and optimum temperature for the production and germination of basidiospores was $20^{\circ} \mathrm{C}$ but the temperature required for high infection was $20-25^{\circ} \mathrm{C}$ (Morin et al., 1992). The researchers reported in their field experiment that pathogen herbivore (Puccinia xanthii Schwein. f. sp. Ambrosiaetrifidae S.W.T. Batra) is an obligate parasitic rust fungus recorded an effective biocontrol agent against giant ragweed (Zhang et al., 2011a; Lu et al., 2004c; Seier et al., 2009; Batra, 1981) used as mycoherbicides against Ambrosia species (Wilson, 1969; Hasan, 1974; Barreto and Evans, 1995).

\section{Life stages of pathogen herbivore}

The pathogen herbivore (Puccinia xanthii) is an obligate parasite overwinters in the form of yellow powder of spores in dead plants at high humidity (Dhileepan, 2001; Qu et al., 2009). Its initial symptoms are clearly identified on leaves and its infection causes reduced plant growth rates and, dark brown telia appears clearly, easily identified on the whole leaves (Fig. 12).

\section{Response of root herbivore on common ragweed (Ambrosia artemisifolia L.)}

The present study suggested that root herbivore (Fire ants) is a biological control agent on common ragweed (A. artemisifolia) present in site $\mathrm{I}$ at $26^{\circ} \mathrm{C}\left(22-31^{\circ} \mathrm{C}\right)$ near Hanhe River. These results are in line with the researchers who reported that environmental conditions played a vital role for the development of root herbivore, however optimum temperature required for its foraging was between $25-35^{\circ} \mathrm{C}$ (Drees et al., 2007). Multivariate analysis suggested that biological control herbivores recorded significant $(\mathrm{P}<0.05)$ reduction in growth parameters of invasive weed compared to control treatment. This herbivore affected root portion resulted in significant $(\mathrm{P}<0.05)$ reduction of growth parameters of invasive weed compared to control. The experiment 
suggested that the trend of plant height $(30.62 \%)$, stem diameter $(43.21 \%)$ and number of leaves $(73.60 \%)$ of the $A$. artemisifolia decreased significantly $(\mathrm{P}<0.05)$ due to biting behaviour of root herbivores compared to control. Scientists studied plant mortality up to $12.5-17.2 \%$ in grooves (Smittle et al., 1988), calyx feeding resulted in reduction of $50 \%$ flowers (Adams, 1986) due to root herbivores. Root herbivores constructed furrows/holes in the stem, hypocotyls portion and reduced plants height. The results of this study are in line with the researchers who reported that root herbivore reduced plant height significantly $(\mathrm{P}<0.05)$ having potential to feed on carbohydrates and polysaccharides from the root tissues (Stewart and Vinson, 1991).

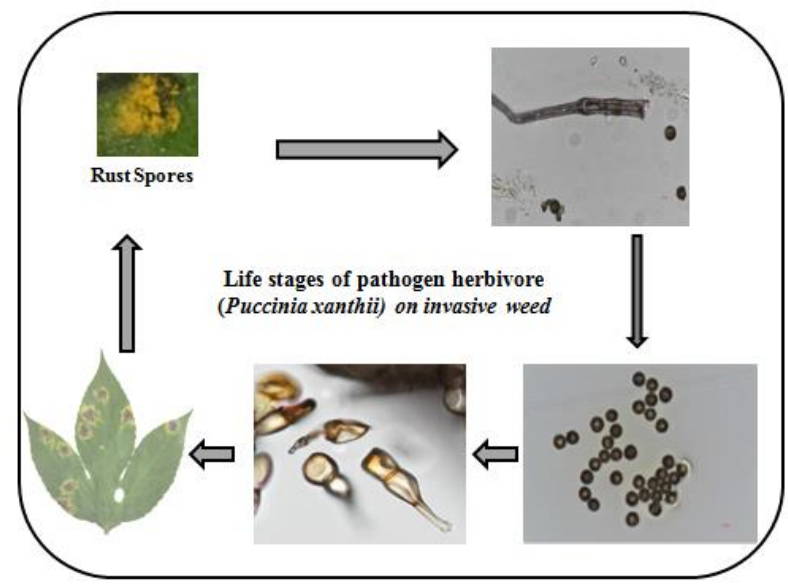

Figure 12. Life stages of pathogen herbivore completed on Ambrosia trifida leaves identified with $40 \mu \mathrm{m}$ and $100 \mu \mathrm{m}$ magnification under microscope

Our results are also in accordance with the researchers who reported that polyphagous ant (Hymenoptera: Formicidae) thinning the root collars that interrupt nutrient supply between shoots and roots (Niu et al., 2010; Vörös and Gallé, 2002) recorded significant damage to the plants. Root herbivores have high reproductive and distribution capabilities, toxic and non-toxic belongings of stings and forceful scavenging performance (Allen et al., 2004; Parris et al., 2002). Root herbivores store small portion of food material to the nest but also assist to crash bigger food item along its transportation (Tschinkel, 2006). These results are in accordance to the researchers who reported that growth and plant height reduced significantly by feeding of fire ant root herbivore (Adams, 1983). Oil contents and carbohydrates (polysaccharides, glucose, and fructose) are necessary ingredients in the diet of ants (root herbivores). Therefore, these herbivores scratch the sap from root portion may be associated with their necessary nutritional carbohydrates (Vander Meer et al., 1995) from plant tissues. The researchers investigated that root herbivore feed on the bark and cambium to obtain sap resulting the death of orange and grapefruit plants in Florida (Banks et al., 1991). Root herbivore (ants) attack on the stems of sunflower at ground level, removed phloem tissue leaving the woody cortex however, $40-50 \%$ of the crop was infested (Stewart and Vinson, 1991). In our experiment root herbivore significantly $(\mathrm{P}<0.05)$ reduced the plant growth characteristics of $A$. artemisifolia compared to gall forming stem herbivore. The hypothesis was proved that root herbivore having capability to injure the roots of invasive $A$. artemisifolia resulting in significant reduction in plant growth characteristics. 
This study shows that gall forming stem insect and pathogen herbivores have potential biological control agent against Ambrosia trifida recorded significant abundance $(\%)$ regarding leave area consumption. During filed survey it had observed that plant hoppers suck the cell sap from the basal portions of stem tissues of $A$. Artemisifolia plant. In future, it may become a biological control agent (BCA's) of this invasive weed. The study also described that root herbivore significantly reduced the growth characteristics of A. artemisifolia may become a promising candidate for BCA's in future.

\section{Conclusion}

The present study concluded that pathogen herbivores deliberated and caused significant effect on giant ragweed (Ambrosia trifida L.). The root, stem galling insect and pathogen herbivores having biologically effective and helpful in reducing the growth characteristics of the Ambrosia species in natural ecosystems. In future, there is a dire need to find out more natural enemies having biologically control efficiency against invasive weeds. In the light of our study, we encouraged the entomologists, plant pathologists and ecologists to explore the mode of action of these herbivores along with phyto-chemical screening and their interactions mechanism on invasive weeds. However, reciprocal relationship of root herbivores with roots of the invasive weeds would be studied in future.

Acknowledgements. This study was supported by the National Key R\&D Program of China (2017YFC1200101), the National Natural Science Foundation of China (31470575, 31670545 and 31971557).

Author's contributions. All authors have contributed equally to this paper.

Conflict of interests. All authors declare no conflict of interests.

\section{REFERENCES}

[1] Adams, C. T. (1983): Destruction of eggplants in Marion County, Florida by red imported fire ants (Hymenoptera: Formicidae). - The Florida Entomologist 66: 518-520.

[2] Adams, C. T. (1986): Agricultural and medical impact of the imported fire ants. - Fire ants and leaf cutting ants: biology and management. Westview Press, Boulder, CO 435: 48-57.

[3] Ahmed, M., Ji, M., Qin, P., Gu, Z., Liu, Y., Sikandar, A., Iqbal, M. F., Javeed, A. (2019): Phytochemical screening, total phenolic and flavonoids contents and antioxidant activities of Citrullus colocynthis L. and Cannabis sativa L. - Applied Ecology and Environmental Research 17: 6961-6979.

[4] Allen, C. R., Epperson, D. M., Garmestani, A. S. (2004): Red imported fire ant impacts on wildlife: a decade of research. - The American Midland Naturalist 152: 88-104.

[5] Andersen, K. M., Naylor, B. J., Endress, B. A., Parks, C. G. (2015): Contrasting distribution patterns of invasive and naturalized non-native species along environmental gradients in a semi-arid montane ecosystem. - Applied Vegetation Science 18: 683-693.

[6] ArcGis, E. (2013): Version 10.2. 0. - Redlands: Environmental Systems Research Institute

[7] Balami, S., Thapa, L. B. (2017): Herbivory damage in native Alnus nepalensis and invasive Ageratina adenophora. - Botanica Orientalis: Journal of Plant Science 11: 7-11. 
[8] Banks, W. A., Adams, C. T., Lofgren, C. S. (1991): Damage to young citrus trees by the red imported fire ant (Hymenoptera: Formicidae). - Journal of Economic Entomology 84: 241-246.

[9] Barreto, R. W., Evans, H. C. (1995): The mycobiota of the weed Mikania micrantha in southern Brazil with particular reference to fungal pathogens for biological control. Mycological Research 99: 343-352.

[10] Bassett, I. J., Crompton, C. W. (1975): The biology of Canadian weeds.: 11. Ambrosia artemisiifolia L. and A. psilostachya DC. - Canadian Journal of Plant Science 55: 463476.

[11] Bastiaans, L., Paolini, R., Baumann, D. T. (2008): Focus on ecological weed management: what is hindering adoption? - Weed Research 48: 481-491.

[12] Batra, S. W. T. (1981): Puccinia xanthii forma specialis ambrosia-trifidae. Mycopathologia 73: 61-64.

[13] Bincheng, Z. (1994): Index of economically important Lepidoptera. - CAB International $599 \mathrm{p}$.

[14] Brown, R. L. (1973): Phylogenetic systematics: its application to the genus Epiblema (Lepidoptera). Fayetteville, AR: University of Arkansas; 1973. 179 p. -

[15] Bullock, J. M., Chapman, D., Schafer, S., Roy, D., Girardello, M., Haynes, T., Beal, S., Wheeler, B., Dickie, I., Phang, Z. (2012): Assessing and controlling the spread and the effects of common ragweed in Europe. - Final Report to the European Commission, DG Environment. Wallington, UK: Centre for Ecology and Hydrology.

[16] Butchart, S. H. M., Walpole, M., Collen, B., Van Strien, A., Scharlemann, J. P. W., Almond, R. E. A., Baillie, J. E. M., Bomhard, B., Brown, C., Bruno, J. (2010): Global biodiversity: indicators of recent declines. - Science 328: 1164-1168.

[17] Buttenschøn, R. M., Waldispühl, S., Bohren, C. (2010): Guidelines for management of common ragweed, Ambrosia artemisiifolia. - Technical report, http:/www.EUPHRESCO.org

[18] Chao, A., Chazdon, R. L., Colwell, R. K., Shen, T. J. (2005): A new statistical approach for assessing similarity of species composition with incidence and abundance data. Ecology letters 8: 148-159.

[19] Chen, H., Chen, L., Albright, T. P. (2007): Developing habitat-suitability maps of invasive ragweed (Ambrosia artemisiifolia. L) in China using GIS and statistical methods.- GIS for Health and the Environment, Springer, In: International Conference in GIS and Health; GIS for health and the environment: development in the Asia-Pacific region, Springer, Berlin, pp. 105-121,

[20] Chollet, D. (1999): Lutte contre l'ambroisie a feuille d'armoise. - Perspect. Agric. 250: 78-82.

[21] Committee, F. O. C. E. (2011): Ambrosia trifida Linnaeus. - Accessed online February 132018.

[22] Debaeke, P., Caussanel, J. P., Kiniry, J. R., Kafiz, B., Mondragon, G. (1997): Modelling crop: weed interactions in wheat with ALMANAC. - Weed Research 37: 325-341.

[23] Dhileepan, K. (2001): Effectiveness of introduced biocontrol insects on the weed Parthenium hysterophorus (Asteraceae) in Australia. - Bulletin of entomological research 91: 167-176.

[24] Dhileepan, K., Callander, J., Shi, B., Osunkoya, O. O. (2018): Biological control of parthenium (Parthenium hysterophorus): the Australian experience. - Biocontrol science and technology 28: 970-988.

[25] Dhileepan, K., McFadyen, R. E. C. (2001): Effects of gall damage by the introduced biocontrol agent Epiblema strenuana (Lep., Tortricidae) on the weed Parthenium hysterophorus (Asteraceae). - Journal of Applied Entomology 125: 1-8.

[26] Drees, B. M., Summerlin, B., Vinson, S. B. (2007): Foraging activity and temperature relationship for the red imported fire ant. - Southwestern Entomologist 32: 
[27] El-Azazi, E.-S., Khalifa, E. A., Belal, M. M. S. A. H., Eltanger, N. A. (2013): Ecological studies of some Acacia species grown in Egyptian Deserts. - Earth 7: 3-8542.

[28] EPPO (2008): Ambrosia artemisiifolia (AMBEL). - Bulletin OEPP/EPPO Bulletin 38: 414-418.

[29] Essl, F., Biró, K., Brandes, D., Broennimann, O., Bullock, J. M., Chapman, D. S., Chauvel, B., Dullinger, S., Fumanal, B., Guisan, A. (2015): Biological flora of the British Isles: Ambrosia artemisiifolia. - Journal of Ecology 103: 1069-1098.

[30] Feng-feng, D. A. I., Zao-hong, Z., You-gang, H. E., Zao-fa, J. (2002): Preliminary Investigation on Occurrence Law of Epiblema strenuana A Natural Enemy of Ambrosia antemisiifolia [J]. - Acta Agriculturae Jiangxi 4:

[31] GBIF (2018): Ambrosia trifida L. - Accessed online January 292018. https://www.gbif.org/species/3110588:

[32] Goodwin, P. H., Hsiang, T. (2010): Quantification of fungal infection of leaves with digital images and Scion Image software.- Molecular and Cell Biology Methods for Fungi, Springer,

[33] Goplen, J. J., Sheaffer, C. C., Becker, R. L., Coulter, J. A., Breitenbach, F. R., Behnken, L. M., Johnson, G. A., Gunsolus, J. L. (2016): Giant ragweed (Ambrosia trifida) seed production and retention in soybean and field margins. - Weed Technology 30: 246-253.

[34] Guozhong, L., Fengxuan, G., Xinran, S., Xiaodong, S., Hua, J. (2018): The rust fungus of Puccinia Xanthii f. sp. Ambrosiae-trifidae being a good biocontrol agent of giant ragweed. - Applied Microbiology 4: 67.

[35] Hasan, S. (1974): Recent advances in the use of plant pathogens as biocontrol agents of weeds. - PANS Pest Articles \& News Summaries 20: 437-443.

[36] Heinrich, C. (1923): Revision of the North American moths of the subfamily Eucosminae of the family Olethreutidae.-US Government Printing Office,

[37] Hejda, M., Pyšek, P., Pergl, J., Sádlo, J., Chytrý, M., Jarošík, V. (2009): Invasion success of alien plants: do habitat affinities in the native distribution range matter? - Global Ecology and Biogeography 18: 372-382.

[38] Hennen, J. F., Figueiredo, M. B., Carvalho Jr, A. A., Hennen, P. G. (2005): Catalogue of the species of plant rust fungi (Uredinales) of Brazil. - Jardim Botanico do Rio de Janeiro: Rio de Janeiro, Brazil

[39] Hossain, S. A. A. M., Wang, L., Chen, T., Li, Z. (2017): Leaf area index assessment for tomato and cucumber growing period under different water treatments. - Plant, Soil and Environment 63: 461-467.

[40] Iqbal, M. F., Feng, Y. L., Liu, M. C., Lu, X. R., Nasir, M., Sikandar, A. (2019): Parasitic activity of powdery mildew (Pathogen strain HMLAC 226) on prostrate knotweed (Polygonum aviculare L.) at various locations of Shenyang, Northeast China. - Applied Ecology and Environmental Research 17: 13383-13394.

[41] Kazinczi, G., Béres, I., Novák, R., Bíró, K., Pathy, Z. (2008): Common ragweed (Ambrosia artemisiifolia): a review with special regards to the results in Hungary. I. Taxonomy, origin and distribution, morphology, life cycle and reproduction strategy. Herbologia 9: 55-91.

[42] Kilewa, R., Rashid, A. (2014): Distribution of invasive weed Parthenium hysterophorus in natural and agro-ecosystems in Arusha Tanzania. - International Journal of Science and Research 3: 1-4.

[43] Kiss, L. (2007): Why is biocontrol of common ragweed, the most allergenic weed in Eastern Europe, still only a hope. - Biological control: A global perspective 80-91.

[44] Kőmíves, T., Béres, I., Reisinger, P., Lehoczky, E., Berke, J., Tamás, J., Páldy, A., Csornai, G., NáDor, G., Kardeván, P. (2006): New strategy of the integrated protection against common ragweed (Ambrosia artemisiifolia L.). - Magyar Gyomkutatás és Technológia 7: 5-49. 
[45] Kumar, S., Graham, J., West, A. M., Evangelista, P. H. (2014): Using district-level occurrences in MaxEnt for predicting the invasion potential of an exotic insect pest in India. - Computers and Electronics in Agriculture 103: 55-62.

[46] Lambertini, M., Leape, J., Marton-Lefevre, J., Mittermeier, R. A., Rose, M., Robinson, J. G., Stuart, S. N., Waldman, B., Genovesi, P. (2011): Invasives: a major conservation threat. - Science 333: 404-405.

[47] Letourneau, D. K., Jedlicka, J. A., Bothwell, S. G., Moreno, C. R. (2009): Effects of Natural Enemy Biodiversity on the Suppression of Arthropod Herbivores in Terrestrial Ecosystems. - Annual Review of Ecology, Evolution, and Systematics 40: 573-592.

[48] Lowman, M. D. (1984): An assessment of techniques for measuring herbivory: is rainforest defoliation more intense than we thought? - Biotropica 264-268.

[49] Lu, G., Yang, H., Sun, X., Yang, R., Zhao, Z. (2004a): Puccinia xanthii f. sp. ambrosiaetrifidae, a newly recorded rust taxon on Ambrosia in China. - Mycosystema 23: 310-311.

[50] Lu, G. Z., Yang, H., Qu, B., Huang, G. K., Chen, W. Z., Cannon, P. (2004b): Ultrastructure observation of Puccinia xanthii Schwein. f. sp. ambrosia-trifidae SWT Batra. - J. Fung. Res 2: 14-16.

[51] Lu, G. Z., Yang, H., Sun, X. D., Yang, Y. X., Zhao, Z. H. (2004c): Puccinia xanthii Schwein. f. sp. ambrosia-trifidae SWT Batra, a newly recorded rust taxon on Ambrosia in China. - Mycosystema 23: 612-614.

[52] Ma, J., Wan, F.-H., Guo, J.-Y., You, L.-S. (2003): Bio-climatic matching analysis for Epiblema strenuana (Lepidoptera: Tortricidae) in China. - Scientia Agricultura Sinica 10 :

[53] Magurran, A. E. (1988): Why diversity?- Ecological diversity and its measurement, Springer,

[54] Mahajan, M., Fatima, S. (2017): Frequency, abundance, and density of plant species by list count quadrat method. - International Journal of Multidisciplinary Research 3: 1-8.

[55] Mayer, D. G., Butler, D. G. (1993): Statistical validation. - Ecological modelling 68: 2132.

[56] McClay, A. S. (1987): Observations on the biology and host specificity of Epiblema strenuana (Lepidoptera, Tortricidae), a potential biocontrol agent for Parthenium hysterophorus (Compositae). - Entomophaga 32: 23-34.

[57] McFadyen, R. C. (1992): Biological control against parthenium weed in Australia. - Crop protection 11: 400-407.

[58] McFadyen, R. E. C. (1998): Biological control of weeds. - Annual review of entomology 43: 369-393.

[59] Meng, L., Li, B. P. (2005): Advances on biology and host specificity of the newly introduced beetle, Ophraella communa Lesage (Coleoptera: Chrysomelidae), attacking Ambrosia artemisiifolia (Compositae) in continent of China. - Chinese Journal of Biological Control 21: 65-69.

[60] Moles, A. T., Westoby, M. (2000): Do small leaves expand faster than large leaves, and do shorter expansion times reduce herbivore damage? - Oikos 90: 517-524.

[61] Morin, L., Auld, B. A., Brown, J. F. (1993): Host range of Puccinia xanthii and postpenetration development on Xanthium occidentale. - Canadian Journal of Botany 71: 959-965.

[62] Morin, L., Brown, J. F., Auld, B. A. (1992): Teliospore germination, basidiospore formation and the infection process of Puccinia xanthii on Xanthium occidentale. Mycological Research 96: 661-669.

[63] Moskalenko, G. P. (2002): Common ragweed. - Zashchita i Karantin Rastenii 2: 38-41.

[64] Murphy, S. J., Audino, L. D., Whitacre, J., Eck, J. L., Wenzel, J. W., Queenborough, S. A., Comita, L. S. (2015): Species associations structured by environment and land-use history promote beta-diversity in a temperate forest. - Ecology 96: 705-715. 
[65] Niu, Y., Feng, Y.-L., Xie, J., Luo, F. (2010): Noxious invasive Eupatorium adenophorum may be a moving target: Implications of the finding of a native natural enemy, Dorylus orientalis. - Chinese Science Bulletin 55: 3743-3745.

[66] O’Neal, M. E., Landis, D. A., Isaacs, R. (2002): An inexpensive, accurate method for measuring leaf area and defoliation through digital image analysis. - Journal of Economic Entomology 95: 1190-1194.

[67] Pál, R. (2004): Invasive plants threaten segetal weed vegetation of South Hungary. Weed technology 18: 1314-1319.

[68] Parris, L. B., Lamont, M. M., Carthy, R. R. (2002): Increased incidence of red imported fire ant (Hymenoptera: Formicidae) presence in loggerhead sea turtle (Testudines: Cheloniidae) nests and observations of hatchling mortality. - Florida Entomologist 85: 514-518.

[69] Pinke, G., Karácsony, P., Czúcz, B., Botta-Dukat, Z. (2011): Environmental and land-use variables determining the abundance of Ambrosia artemisiifolia in arable fields in Hungary. - Preslia 83: 219-235.

[70] Powell, K. I., Chase, J. M., Knight, T. M. (2011): A synthesis of plant invasion effects on biodiversity across spatial scales. - American Journal of Botany 98: 539-548.

[71] Protopopova, V. V., Shevera, M. V., Mosyakin, S. L. (2006): Deliberate and unintentional introduction of invasive weeds: A case study of the alien flora of Ukraine. Euphytica 148: 17-33.

[72] Qu, B., Yang, H., Dong, S. (2009): Incidence and epidemics of giant ragweed rust (Puccina xanthii f. sp. ambrosiae-trifidae). - Journal of Fungal Research 7: 180-184.

[73] Qureshi, H., Arshad, M., Bibi, Y. (2014): Invasive flora of Pakistan: a critical analysis. International Journal of Biosciences 4: 407-424.

[74] Qureshi, H., Arshad, M., Bibi, Y., Osunkoya, O. O., Adkins, S. W. (2018): Multivariate impact analysis of Parthenium hysterophorus invasion on above-ground plant diversity of Pothwar region of Pakistan. - Applied Ecology and Environmental Research 16: 57995813.

[75] Reznik, S. Y. (2009): Common ragweed (Ambrosia artemisiifolia L.) in Russia: spread, distribution, abundance, harmfulness and control measures. - Ambroisie, The first international ragweed review 200926:

[76] Riaz, T., Javaid, A. (2011): Prevalence of alien weed Parthenium hysterophorus L. in grazing and wastelands of District attock, Pakistan. - Journal of Animal and Plant Science 21: 542-545.

[77] Royo-Esnal, A., Torra, J., Conesa, J. A., Forcella, F., Recasens, J. (2010): Modeling the emergence of three arable bedstraw (Galium) species. - Weed Science 58: 10-15.

[78] Seier, M. K., Morin, L., Evans, H. C., Romero, Á. (2009): Are the microcyclic rust species Puccinia melampodii and Puccinia xanthii conspecific? - Mycological Research 113: $1271-1282$.

[79] Smittle, B. J., Adams, C. T., Banks, W. A., Lofgren, C. S. (1988): Red imported fire ants: feeding on radiolabeled citrus trees. - Journal of economic entomology 81: 1019-1021.

[80] Stewart, J. W., Vinson, S. B. (1991): Red imported fire ant damage to commercial cucumber and sunflower plants. - Southwestern Entomologist 16: 168-1760.

[81] Strother, J. L. (2006): Ambrosia Linnaeus, pp. 10-18. In Flora of North America Editorial Committee (ed.), Flora of North America: North of Mexico vol 21 Magnoliophyta: Asteridae, Part 8: Asteraceae, Part 3. Oxford University Press. -

[82] Tóth, Á., Hoffmanné, P. Z., Szentey, L. (2004): A parlagfü (Ambrosia elatior) helyzet 2003-ban Magyarországon. - A levegő pollenszám csökkentésének nehézségei 14:

[83] Tschinkel, W. R. (2006): The fire ants.-Harvard University Press,

[84] Ustinova, A. F., Sizovenko, L. E. (2006): Invasive weeds in Ukraine. - Zashchita i Karantin Rastenii 9: 27-29. 
[85] Vander Meer, R. K., Lofgren, C. S., Seawright, J. A. (1995): Specificity of the red imported fire ant (Hymenoptera: Formicidae) phagostimulant response to carbohydrates. - Florida Entomologist 144-154.

[86] Vilà, M., Espinar, J. L., Hejda, M., Hulme, P. E., Jarošík, V., Maron, J. L., Pergl, J., Schaffner, U., Sun, Y., Pyšek, P. (2011): Ecological impacts of invasive alien plants: a meta-analysis of their effects on species, communities and ecosystems. - Ecology letters 14: 702-708.

[87] Vörös, G., Gallé, L. (2002): Ants (Hymenoptera: Formicidae) as primary pests in Hungary: recent observations. - Tiscia 33: 31-35.

[88] Wahyuno, D. (2012): Puccinia xanthii Penyebab Bercak Daun pada Xanthium sp. di Indonesia. - Jurnal Fitopatologi Indonesia 8: 116-119.

[89] Wan, F. H., Wang, R., Ding, J. 1995: Biological control of Ambrosia artemisiifolia with introduced insect agents, Zygogramma suturalis and Epiblema strenuana. - Proceedings of the eighth international symposium on biological control on weeds. 193-200.

[90] Wilson, C., Tisdell, C. (2001): Why farmers continue to use pesticides despite environmental, health and sustainability costs. - Ecological economics 39: 449-462.

[91] Wilson, C. L. (1969): Use of plant pathogens in weed control. - Annual Review of Phytopathology 7: 411-434.

[92] Yaacoby, T., Seplyarsky, V. (2011): Epiblema strenuana (Walker, 1863)(Lepidoptera: Tortricidae), a new species in Israel. - EPPO Bulletin 41: 243-246.

[93] Zereen, A., Ahmad, S. S., Jahan, A. (2018): Determination of correlation between plant distribution and ecological factors in Narowal district Punjab, Pakistan. - Bangladesh Journal of Botany 47: 451-458.

[94] Zhang, P., Lu, G.-z., Sun, X.-d., Zhang, W., Qu, B., Tian, X.-1. (2011a): The infection process of Puccinia xanthii f. sp. Ambrosiae-trifidae on Ambrosia trifida. - Botany 89: 771-777.

[95] Zhang, W., Jiang, F., Ou, J. (2011b): Global pesticide consumption and pollution: with China as a focus. - Proceedings of the International Academy of Ecology and Environmental Sciences 1: 125.

[96] Zhao, Y. Z., Feng, Y. L., Liu, M. C., Liu, Z. H. (2014): First Report of Rust Caused by Puccinia xanthii on Xanthium orientale subsp. italicum in China. - Plant disease 98: 1582-1582.

[97] Zhou, Z.-S., Chen, H.-S., Zheng, X.-W., Guo, J.-Y., Guo, W., Li, M., Luo, M., Wan, F.H. (2014): Control of the invasive weed Ambrosia artemisiifolia with Ophraella communa and Epiblema strenuana. - Biocontrol Science and Technology 24: 950-964.

[98] Zhou, Z.-S., Guo, J.-Y., Chen, H.-S., Wan, F.-H. (2010): Effects of temperature on survival, development, longevity, and fecundity of Ophraella communa (Coleoptera: Chrysomelidae), a potential biological control agent against Ambrosia artemisiifolia (Asterales: Asteraceae). - Environmental Entomology 39: 1021-1027.

[99] Zhou, Z., Wan, F., Guo, J. (2017): Common Ragweed Ambrosia artemisiifolia L. Biological Invasions and Its Management in China, Springer 2:99-109. 